\title{
Erwinia oleae sp. nov., isolated from olive knots caused by Pseudomonas savastanoi pv. savastanoi
}

Correspondence

Chiaraluce Moretti chiaraluce.moretti@unipg.it

\author{
Chiaraluce Moretti, ${ }^{1} \dagger$ Taha Hosni, ${ }^{1} \dagger$ Katrien Vandemeulebroecke, ${ }^{2}$ \\ Carrie Brady, ${ }^{3}$ Paul De Vos, ${ }^{2}$ Roberto Buonaurio ${ }^{1}$ and Ilse Cleenwerck ${ }^{2}$ \\ ${ }^{1}$ Dipartimento di Scienze Agrarie e Ambientali, University of Perugia, Perugia, Italy \\ ${ }^{2}$ BCCM/LMG Bacteria Collection, Ghent University, Ghent, Belgium \\ ${ }^{3}$ LM-UGent, Laboratory of Microbiology, Faculty of Sciences, Ghent University, Ghent, Belgium
}

\begin{abstract}
Three endophytic bacterial isolates were obtained in Italy from olive knots caused by Pseudomonas savastanoi pv. savastanoi. Phenotypic tests in combination with 16S rRNA gene sequence analysis indicated a phylogenetic position for these isolates in the genera Erwinia or Pantoea, and revealed two other strains with highly similar $16 \mathrm{~S}$ rRNA gene sequences (>99\%), CECT 5262 and CECT 5264, obtained in Spain from olive knots. Rep-PCR DNA fingerprinting of the five strains from olive knots with BOX, ERIC and REP primers revealed three groups of profiles that were highly similar to each other. Multilocus sequence analysis (MLSA) based on concatenated partial atpD, gyrB, infB and $r p o B$ gene sequences indicated that the strains constituted a single novel species in the genus Erwinia. The strains showed general phenotypic characteristics typical of the genus Erwinia and whole genome DNA-DNA hybridization data confirmed that they represented a single novel species of the genus Erwinia. The strains showed DNA G $+C$ contents ranging from 54.7 to $54.9 \mathrm{~mol} \%$. They could be discriminated from phylogenetically related species of the genus Erwinia by their ability to utilize potassium gluconate, L-rhamnose and D-arabitol, but not glycerol, inositol or D-sorbitol. The name Erwinia oleae sp. nov. (type strain DAPP-PG $531^{\top}=L M G 25322^{\top}=$ DSM $23398^{\top}$ ) is proposed for this novel taxon.
\end{abstract}

Knot formation on olive trees (Olea europaea L.) is a serious disease found in many olive producing areas. It is caused by Pseudomonas savastanoi pv. savastanoi and characterized by outgrowth on trunks and branches, and less frequently leaves and fruits (Sisto et al., 2004). Olive knots are ideal niches for bacterial growth, not only of the causal agent of the disease, but also of a number of endophytic members of the class Gammaproteobacteria such as Erwinia toletana (Rojas et al., 2004), Pantoea agglomerans (Marchi et al., 2006; Quesada et al., 2007) and other bacteria from the genera Burkholderia, Hafnia, Pseudomonas and Stenotrophomonas (Ouzari et al., 2008). In the last few years, several studies have focussed on the effect of these endophytes in modulating olive knot

†These authors contributed equally to this work.

Abbreviation: MLSA, multilocus sequence analysis.

The GenBank/EMBL/DDBJ accession number for the 16S rRNA gene sequence of strain DAPP-PG $531^{\top}$ is GU810925. The accession numbers for the atp $D$, gyr $B$, infB and $r p o B$ gene sequences of strains DAPP-PG 531' ${ }^{\top}$, DAPP-PG 672 and CECT 5264 are GU991653GU991656, HM439616-HM439619 and HM439612-HM439615, respectively.

A supplementary table and four supplementary figures are available with the online version of this paper. disease severity (Marchi et al., 2006; Hosni, 2010). As such, it has been shown that Pantoea agglomerans, frequently isolated from olive knots when inoculated in olive plants together with Pseudomonas savastanoi pv. savastanoi, can either depress growth of the pathogen or produce an increase in knot size (Marchi et al., 2006).

In the present study, five endophytic strains from olive knots (DAPP-PG 531 ${ }^{\mathrm{T}}$, DAPP-PG 537, DAPP-PG 672, CECT 5262 and CECT 5264) were investigated using a polyphasic taxonomic approach.

In September 2003 and May 2007, young knots from branches of diseased olive trees located in orchards at Scanzano in the province of Perugia (Umbria, central Italy) and Valenzano in the province of Bari (Apulia, south Italy) were collected. Small portions of their internal watersoaked tissue were excised with a scalpel and crushed in a few drops of sterile distilled water. Subsequently, a loopful of the suspensions was streaked onto nutrient agar (NA; Oxoid) and the plates incubated at $27 \pm 1{ }^{\circ} \mathrm{C}$ for 2 days. Along with circular $(0.5-2.9 \mathrm{~mm}$ in diameter), white to pale yellow colonies resembling a 'fried egg', typical for Pseudomonas savastanoi pv. savastanoi, another bacterial colony type was frequently isolated. The latter type was 
selected for further investigation. Pure cultures of this type were obtained by picking up a single colony and streaking it onto NA plates amended with $5 \%$ sucrose. This way, strains DAPP-PG $531^{\mathrm{T}}$ and DAPP-PG 537 were obtained in 2003 and strain DAPP-PG 672 in 2007. Initial microbiological characterization of these strains revealed that their colonies were not fluorescent when cultivated on King's medium B (20 g peptone $\mathrm{l}^{-1}, 1.5 \mathrm{~g}$ anhydrous $\mathrm{K}_{2} \mathrm{HPO}_{4} \mathrm{l}^{-1}$,

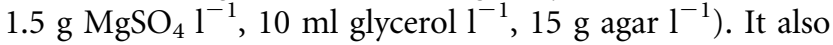
revealed that their cells were Gram-negative (as they lysed in $3 \% \mathrm{KOH}$; Suslow et al., 1982), oxidase-negative, catalasepositive and facultatively anaerobic, suggesting that they belonged to the family Enterobacteriaceae. Additional strains used in this study were obtained from various biological resource centres and cultivated following the instructions of the provider. All bacterial strains used in this study are listed in Supplementary Table S1 (available in IJSEM Online).

Genomic DNA was extracted from strain DAPP-PG $531^{\mathrm{T}}$ according to the protocol of Niemann et al. (1997). Amplification of the 16S rRNA gene was performed with the conserved primers 16F27 (5'-AGAGTTTGATCCTGGCTCAG-3') and 16R1522 (5'-AAGGAGGTGATCCAGCCGCA-3'). Purification of the amplification product was conducted with the NucleoFast 96 PCR Clean-up kit (Macherey-Nagel). Sequencing reactions were performed with the internal primers listed by Coenye et al. (1999) using the BigDye Terminator Cycle Sequencing kit (Applied Biosystems). Purification of the sequencing reaction products was conducted using the BigDye XTerminatorT Purification kit (Applied Biosystems). Sequencing was performed using an ABI Prism 3130XL Genetic Analyzer (Applied Biosystems). Sequence assembly was done using the software package BioNumerics (Applied Maths). A nearly complete $16 \mathrm{~S}$ rRNA gene sequence (1494 nt) was obtained for strain DAPP-PG $531^{\mathrm{T}}$ and compared with $16 \mathrm{~S}$ rRNA gene sequences deposited at NCBI, using BLAST. This analysis indicated that strain DAPP-PG $531^{\mathrm{T}}$ belonged to the genera Erwinia or Pantoea, and it revealed two strains with very similar $16 \mathrm{~S}$ rRNA gene sequences $(>99 \%$ pairwise similarity), 'Pantoea oleae' CECT 5262 and CECT 5264, that were obtained in Spain from olive knots. Using the software package BioNumerics (Applied Maths), the nearly complete $16 \mathrm{~S}$ rRNA gene sequences of strains DAPP-PG $531^{\mathrm{T}}$, CECT 5262 and CECT 5264 were compared with those of reference strains of species of the genera Erwinia, Pantoea and related taxa collected from GenBank. Pairwise similarities were calculated using an open gap penalty of $100 \%$ and a unit gap penalty of $0 \%$. A neighbour-joining phylogenetic tree (Fig. 1) was constructed using BioNumerics, and the robustness of the branches was evaluated by bootstrap analysis (Felsenstein, 1985). A maximum-likelihood phylogenetic tree was constructed (see Supplementary Fig. S1 in IJSEM Online) as described previously (Brady et al., 2008). The three strains from olive knots showed more than $99 \% 16 \mathrm{~S}$ rRNA gene sequence similarity with each other and less than 97\% with recognized species of the genera Erwinia and Pantoea. As strains showing less than $97 \% 16 \mathrm{~S}$ rRNA gene sequence similarity are not likely to have more than 60-70\% DNA-DNA relatedness (Stackebrandt \& Goebel, 1994), these similarity values strongly suggested that the strains from olive knots represented at least one novel species in the family Enterobacteriaceae.

Genomic DNA was extracted from strains DAPP-PG $531^{\mathrm{T}}$, DAPP-PG 537, DAPP-PG 672, CECT 5262 and CECT 5264 and from Erwinia toletana CFBP $6631^{\mathrm{T}}$ with the GenElute Bacterial Genomic DNA kit (Sigma Aldrich). Rep-PCR fingerprinting was performed with the BOX (Versalovic et al., 1994), ERIC (Hulton et al., 1991) and REP (Higgins et al., 1982; Versalovic et al., 1991) primers, according to the method described by Rademaker \& de Bruijn (1997). Repeat experiments were performed and identical results were obtained. The rep-PCR profiles are shown in Supplementary Fig. S2. Irrespective of the primers used, strains DAPP-PG $531^{\mathrm{T}}$ and DAPP-PG 537 generated the same fingerprints as well as strains CECT 5262 and CECT 5264. The Dice coefficient between the two groups of strains was 0.88 . Strain DAPP-PG 672 had a similarity index of 0.88 with strains DAPP-PG $531^{\mathrm{T}}$ and DAPP-PG 537 and 0.94 with strains CECT 5262 and CECT 5264. E. toletana CFBP $6631^{\mathrm{T}}$ generated different fingerprints and with low similarity (0.36) in comparison with the other tested strains. Based on previous studies (Gevers et al., 2001; De Vuyst et al., 2008), the rep-PCR data suggested that strains DAPP-PG $531^{\mathrm{T}}$, DAPP-PG 537, DAPP-PG 672, CECT 5262 and CECT 5264 probably constituted a single species.

Multilocus sequence analysis (MLSA) of concatenated partial $a t p D, g y r B$, infB and $r p o B$ gene sequences enables the phylogenetically related genera Erwinia, Pantoea and Tatumella to be differentiated from each other (Brady et al., 2008, 2009, 2010a, b, c). To refine the taxonomic position of the five strains from olive knots, partial sequences of the above-mentioned housekeeping genes were determined for three representative strains, DAPP-PG 531 ${ }^{\mathrm{T}}$, DAPP-PG 672 and CECT 5264, and 12 reference strains from recognized species of the genus Erwinia (see Fig. 2 and Supplementary Fig. S3; gene sequences from GenBank accession nos HM439612-HM439619, GU991653-GU991656, HQ393588HQ393635 were determined in this study). Partial fragments of the $\operatorname{atpD}, \operatorname{gyr} B$, infB and $r p o B$ genes for strains DAPPPG 531 ${ }^{\mathrm{T}}$, DAPP-PG 672 and CECT 5264 were amplified and sequenced using the protocol of Brady et al. (2008) with the following modifications: (i) primer atpD 08-R (5'CCGAGCAGCGCGGAGACTTC-3') was used instead of atpD 04-R; (ii) primer infB 05-F (5' -ACGGBATGRTBACSTTCCTKG- $3^{\prime}$ ) was used instead of infB 03-F. The modifications were needed because good technical sequences could not be obtained with primers atpD $04-\mathrm{R}$ and infB 03-F, probably because they could not bind efficiently. Primers atpD $08-\mathrm{R}$ and infB $05-\mathrm{F}$ were designed based on sequences obtained with the primers atpD $03-\mathrm{F}$ and infB $04-\mathrm{R}$, respectively. Sequence assembly was performed using the BioNumerics software package (Applied Maths), and partial nucleotide $a t p D, \operatorname{gyr} B$, infB and $r p o B$ gene sequences were concatenated and aligned with concatenated partial atpD, 


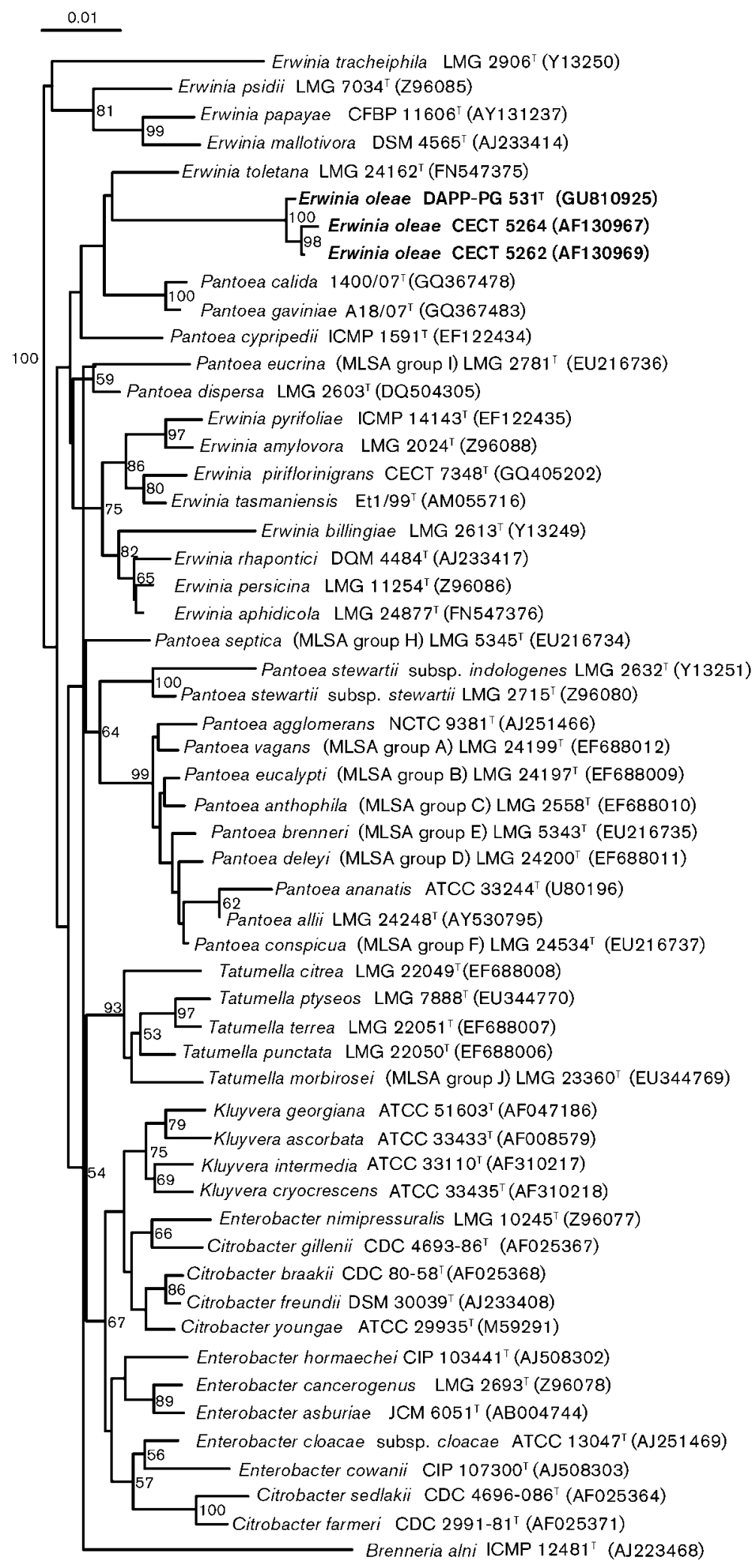

Fig. 1. Neighbour-joining tree based on nearly complete 16S rRNA gene sequences showing the phylogenetic relationship between Erwinia oleae sp. nov. and related taxa within the family Enterobacteriaceae. Brenneria alni ICMP $12481^{\top}$ was used as the outgroup. Bar, $1 \%$ nucleotide substitutions. Numbers at branching points are bootstrap percentage values based on 1000 replications. Only values $>50 \%$ are shown. gyr $B$, inf $B$ and $r p o B$ gene sequences of reference strains of species of the genera Erwinia, Pantoea and Tatumella taken from GenBank. The BioNumerics software package (Applied Maths) was used for this analysis and neighbour-joining and maximum-likelihood phylogenetic trees (Fig. 2 and Supplementary Fig. S3) were constructed as described for the $16 \mathrm{~S}$ rRNA gene. MLSA revealed that strains DAPP-PG $531^{\mathrm{T}}$, DAPP-PG 672 and CECT 5264 belonged to the genus 


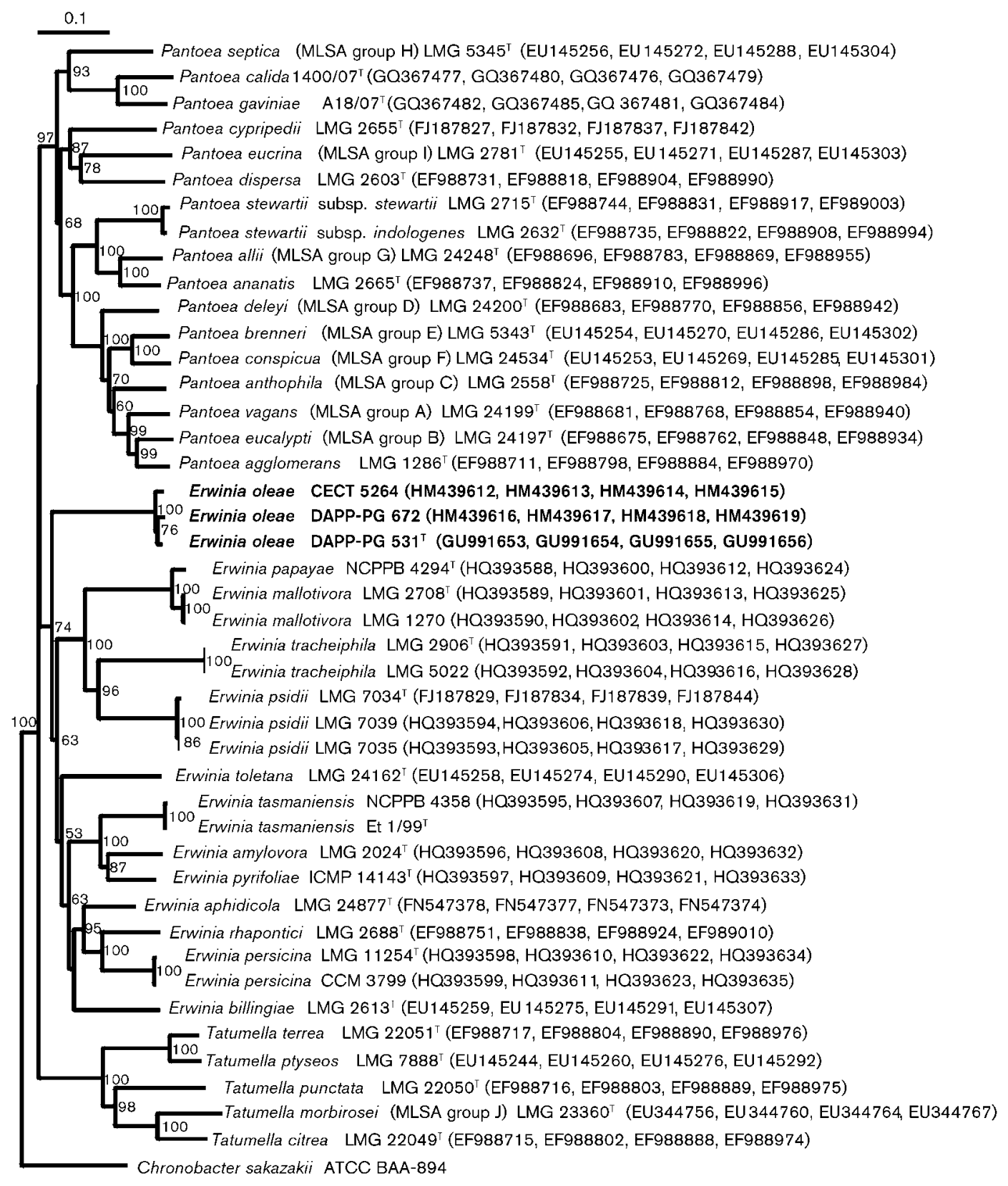

Fig. 2. Neighbour-joining tree based on concatenated partial atp $D$, gyr $B$, infB and rpo $B$ gene sequences showing the phylogenetic relationship between Erwinia oleae sp. nov. and related taxa of the genera Erwinia, Pantoea and Tatumella. Cronobacter sakazakii ATCC BAA-894 was included as the outgroup. Bar, $10 \%$ nucleotide substitutions. Numbers at branching points are bootstrap percentage values based on 1000 replications. Only values $>50 \%$ are shown.

Erwinia and also suggested that they probably constituted a single novel species.

Strains DAPP-PG 531 ${ }^{\mathrm{T}}$, DAPP-PG 537, DAPP-PG 672, CECT 5262 and CECT 5264 were subjected to API 20E and API 50CHE systems (bioMérieux), according to the manufacturer's instructions. The results are presented in the species description below. API 50CHE tests were also carried out on type and reference strains of the 12 recognized species of the genus Erwinia. The strains studied are presented in
Supplementary Fig. S4, and the data obtained were analysed numerically to reveal the phenotypic relationship between the five strains from olive knots and the recognized species of the genus Erwinia. A distance matrix was calculated from similarity matrices generated using the Dice coefficient (Dice, 1945) and subjected to the unweighted pair-group method with arithmetic mean (UPGMA) clustering algorithm using NTSYSpc software (Exeter Software) version 2.1. A cophenetic value of 0.86 was determined for this matrix, which indicated a high goodness-of-fit. The dendrogram in 
Supplementary Fig. S4 revealed that strains DAPP-PG $531^{\mathrm{T}}$, DAPP-PG 537, DAPP-PG 672, CECT 5262 and CECT 5264 formed a very homogeneous cluster with an overall similarity of about $93 \%$ that was well discriminated from the 12 recognized species of the genus Erwinia that each formed a separate cluster. It also showed that the five strains from olive knots had phenotypic features common to the genus Erwinia. Table 1 lists a selected number of phenotypic features that enable strains DAPP-PG $531^{\mathrm{T}}$, DAPP-PG 537, DAPP-PG 672, CECT 5262 and CECT 5264 to be differentiated from recognized species of the genus Erwinia, including Erwinia toletana, the phylogenetically most closely related species of the genus also isolated from olive knots. Table 1 also reveals that the strains can be discriminated from each recognized species of the genus Erwinia, including Erwinia piriflorinigrans (López et al., 2011), by at least two characteristics.

To confirm whether or not strains DAPP-PG $531^{\mathrm{T}}$, DAPPPG 537, DAPP-PG 672, CECT 5262 and CECT 5264 truly constituted a single novel species of the genus Erwinia, DNA-DNA hybridizations were performed. High-molecular mass DNA for DNA-DNA hybridization studies and DNA base composition determination was extracted using the method of Wilson (1987), with minor modifications (Cleenwerck et al., 2002). DNA quantity and quality were determined by measuring the absorptions at 260,280 and $234 \mathrm{~nm}$ and only high quality DNA with $\mathrm{A}_{260} / \mathrm{A}_{280}$ and $\mathrm{A}_{234} / \mathrm{A}_{260}$ ratios of $1.8-2.0$ and $0.40-0.60$, respectively, was selected for further use. The size of the DNA was estimated by agarose gel electrophoresis. DNA-DNA hybridizations were performed with strains DAPP-PG $531^{\mathrm{T}}$, DAPP-PG 672 and CECT 5264 and E. toletana LMG $24162^{\mathrm{T}}$ using a modification (Goris et al., 1998; Cleenwerck et al., 2002) of the microplate method described by Ezaki et al. (1989). The hybridization temperature was $44{ }^{\circ} \mathrm{C}$. Reciprocal reactions $(\mathrm{A} \times \mathrm{B}$ and $\mathrm{B} \times \mathrm{A})$ were performed and their variation was generally taken to be within the limits of this method (Goris et al., 1998). The DNA-DNA relatedness values reported are the mean of minimum six hybridizations. Strains DAPP-PG 531 ${ }^{\mathrm{T}}$, DAPP-PG 672 and CECT 5264 exhibited high levels of DNA-DNA relatedness $(>80 \%)$ and showed low levels $(<25 \%)$ with E. toletana LMG $24162^{\mathrm{T}}$ (Table 2). As levels of $60-70 \%$ DNA-DNA relatedness are generally accepted as the limit for species delineation (Wayne et al., 1987), the DNA-DNA hybridization results confirmed that the strains from olive knots represented a single novel species of the genus Erwinia.

The DNA G + C content of strains DAPP-PG $531^{\mathrm{T}}$, DAPPPG 537, DAPP-PG 672, CECT 5262 and CECT 5264 was determined by HPLC according to the method of Mesbah et al. (1989), and varied from 54.7 to $54.9 \mathrm{~mol} \%$, which was within the range reported previously for members of the genus Erwinia (Hauben et al., 1998; Mergaert et al., 1999; Kim et al., 1999; Gardan et al., 2004; Rojas et al., 2004; Geider et al., 2006). The DNA G + C content range was also less than $2 \%$, the generally accepted range within a species.

Table 1. Phenotypic characteristics differentiating strains of Erwinia oleae sp. nov. from other species of the genus Erwinia

Taxa: 1, Erwinia oleae sp. nov. (five strains); 2, E. amylovora LMG $2024^{\mathrm{T}} ; 3$, E. aphidicola LMG $24877^{\mathrm{T}}$; 4, E. billingiae LMG $2613^{\mathrm{T}}$; 5, E. mallotivora LMG $2708^{\mathrm{T}}$; 6, E. papayae CFBP $5189^{\mathrm{T}}$; 7, E. persicina LMG $11254^{\mathrm{T}} ; 8$, E. psidii LMG $7034^{\mathrm{T}}$; 9, E. piriflorinigrans CECT $7348^{\mathrm{T}}$; 10 , E. pyrifoliae ICMP

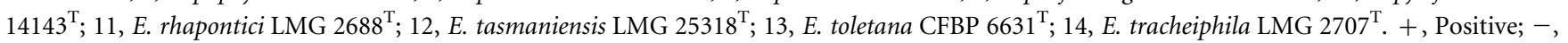
negative; ND, not determined.

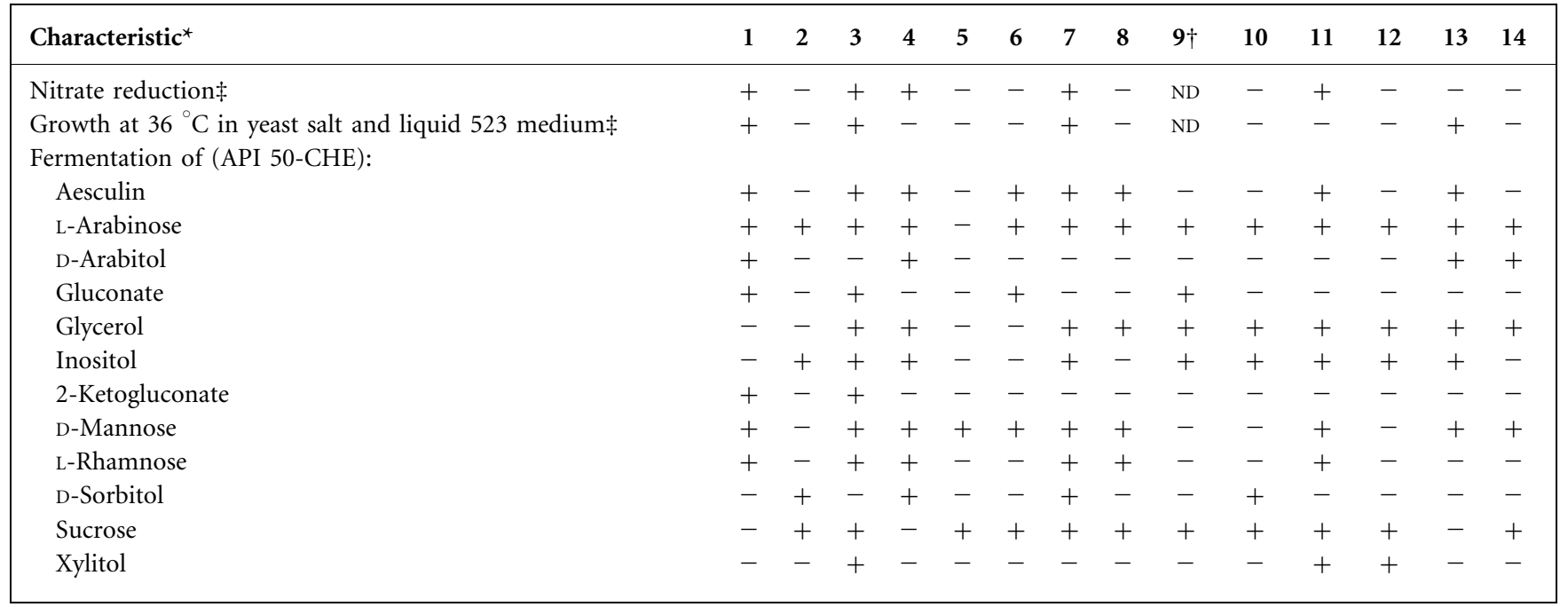

*The strains tested for each Erwinia species are given in Supplementary Table S1.

$\dagger$ Data from López et al. (2011).

$\ddagger$ Tests performed according to Schaad et al. (2001). 
Table 2. DNA-DNA relatedness (\%) between strains DAPPPG $531^{\top}$, DAPP-PG 672 and CECT 5264 of Erwinia oleae sp. nov. and E. toletana LMG $24162^{\top}$

\begin{tabular}{|c|c|c|c|c|}
\hline \multirow[t]{2}{*}{ Strain } & \multicolumn{4}{|c|}{$\begin{array}{l}\text { DNA-DNA relatedness (\%) } \\
\text { with strain*: }\end{array}$} \\
\hline & 1 & 2 & 3 & 4 \\
\hline 1. E. oleae DAPP-PG 672 & 100 & & & \\
\hline 2. E. oleae DAPP-PG $531^{\mathrm{T}}$ & $88 \pm 6$ & 100 & & \\
\hline 3. E. oleae CECT 5264 & $88 \pm 15$ & $89 \pm 16$ & 100 & \\
\hline 4. E. toletana LMG $24162^{\mathrm{T}}$ & $17 \pm 4$ & $14 \pm 5$ & $20 \pm 5$ & 100 \\
\hline
\end{tabular}

${ }^{\star}$ Each value is the mean of a minimum of six hybridizations \pm SD.

In conclusion, based on the genotypic data (from 16S rRNA gene sequence analysis, rep-PCR DNA fingerprinting, MLSA and DNA-DNA hybridizations) and phenotypic data obtained in this study, the five endophytic bacterial strains DAPP-PG 531 ${ }^{\mathrm{T}}$, DAPP-PG 537, DAPP-PG 672, CECT 5262 and CECT 5264 from olive knots, caused by Pseudomonas savastanoi pv. savastanoi, represent a novel species for which the name Erwinia oleae sp. nov. is proposed. Strain DAPPPG $531^{\mathrm{T}}\left(=\mathrm{LMG} 25322^{\mathrm{T}}=\right.$ DSM $\left.23398^{\mathrm{T}}\right)$ is the type strain.

\section{Description of Erwinia oleae sp. nov.}

Erwinia oleae [o'le.ae. L. gen. fem. n. oleae of olive (Olea europaea), the plant from which the bacterium was isolated].

Strains have all the characteristics of members of the family Enterobacteriaceae. Cells are Gram-negative rods, measuring $0.9 \times 1.5-3.0 \mu \mathrm{m}$, and occur as single and pairs. Cells are motile and non-spore-forming. After growth for 24-48 h on nutrient agar at $27 \pm 1{ }^{\circ} \mathrm{C}$, colonies are light beige, circular (1-1.2 $\mathrm{mm}$ in diameter) and convex and with entire margins. Does not produce fluorescent pigment on King's medium B. Growth in yeast salt and liquid 523 medium (Schaad et al., 2001) occurs at $36{ }^{\circ} \mathrm{C}$, but not at $39{ }^{\circ} \mathrm{C}$. Able to grow in $5 \%(\mathrm{w} / \mathrm{v}) \mathrm{NaCl}$. Facultatively anaerobic. Oxidase is not produced. Results obtained with API20E tests (bioMérieux) give a positive result for $\beta$-galactosidase activity, but a negative result for activities of arginine dihydrolase, lysine decarboxylase, ornithine decarboxylase, urease, tryptophan deaminase, phenylalanine deaminase and gelatinase (except strain DAPP-PG 672). Citrate is not utilized; hydrogen sulfide, indole and acetoin (except strains CECT 5262 and CECT 5264) are not produced. Nitrate is reduced to nitrite. Results obtained with API 50CHE tests (bioMerieux) indicate that strains utilize the following substrates as sole carbon sources at $27 \pm 1{ }^{\circ} \mathrm{C}$ within 2 days: $\mathrm{L}$-arabinose, D-ribose, D-galactose, D-glucose, D-fructose, Dmannose, L-rhamnose, D-mannitol, $\mathrm{N}$-acetylglucosamine, aesculin, trehalose, D-arabitol, potassium gluconate and potassium 2-ketogluconate, and arbutin and salicin (except strains DAPP-PG $531^{\mathrm{T}}$ and DAPP-PG 537). The following carbon sources are not utilized at $27 \pm 1{ }^{\circ} \mathrm{C}$ within 2 days: glycerol, erythritol, D-arabinose, D-xylose, L-xylose,
D-adonitol, methyl $\beta$-D-xylopyranoside, L-sorbose, dulcitol, inositol, D-sorbitol, methyl $\alpha$-D-mannopyranoside, methyl $\alpha$-D-glucopyranoside, amygdalin, cellobiose, maltose, lactose, melibiose, sucrose, inulin, melezitose, raffinose, starch, glycogen, xylitol, gentiobiose, turanose, D-lyxose, D-tagatose, D-fucose, L-fucose, L-arabitol and potassium 5-ketogluconate. The DNA G $+\mathrm{C}$ content of the five strains ranges from 54.7 to $54.9 \mathrm{~mol} \%$ as determined by the method of Mesbah et al. (1989).

The type strain, DAPP-PG $531^{\mathrm{T}}\left(=\mathrm{LMG} 25322^{\mathrm{T}}=\right.$ DSM $23398^{\mathrm{T}}$ ) and DAPP-PG 537 (=LMG 25323=DSM 23412), were isolated in Umbria (Italy) from olive knots caused by Pseudomonas savastanoi pv. savastanoi. Additional strains were isolated in Apulia (Italy) (DAPP-PG 672=LMG $25321=$ DSM 23411) and Spain (CECT 5262=LMG 25327, CECT 5264=LMG 25328) also from olive knots caused by Pseudomonas savastanoi pv. savastanoi.

\section{Acknowledgements}

This research was supported by 'Fondazione Cassa di Risparmio di Perugia', Italy, project 'Indagini sui batteri endofiti associati a piante di olivo affette da rogna, volte all'individuazione di nuove strategie di lotta alla malattia' to R. B. The BCCM/LMG Bacteria Collection is supported by the Federal Public Planning Service - Science Policy, Belgium. C. B. is the beneficiary of a fellowship granted by the Federal Science Policy Office, Belgium. The authors wish to acknowledge Katrien Engelbeen and Luca Bonciarelli for their technical support.

\section{References}

Brady, C. L., Cleenwerck, I., Venter, S., Vancanneyt, M., Swings, J. \& Coutinho, T. A. (2008). Phylogeny and identification of Pantoea species associated with plants, humans and the natural environment based on multilocus sequence analysis (MLSA). Syst Appl Microbiol 31, 447-460.

Brady, C. L., Venter, S. N., Cleenwerck, I., Engelbeen, K., Vancanneyt, M., Swings, J. \& Coutinho, T. A. (2009). Pantoea vagans sp. nov., Pantoea eucalypti sp. nov., Pantoea deleyi sp. nov. and Pantoea anthophila sp. nov. Int J Syst Evol Microbiol 59, 2339-2345.

Brady, C. L., Cleenwerck, I., Venter, S. N., Engelbeen, K., De Vos, P. \& Coutinho, T. A. (2010a). Emended description of the genus Pantoea, description of four species from human clinical samples, Pantoea septica sp. nov., Pantoea eucrina sp. nov., Pantoea brenneri sp. nov. and Pantoea conspicua sp. nov., and transfer of Pectobacterium cypripedii (Hori 1911) Brenner et al. 1973 emend. Hauben et al. 1998 to the genus as Pantoea cypripedii comb. nov. Int J Syst Evol Microbiol 60, 2430-2440.

Brady, C. L., Venter, S. N., Cleenwerck, l., Vandemeulebroecke, K., De Vos, P. \& Coutinho, T. A. (2010b). Transfer of Pantoea citrea, Pantoea punctata and Pantoea terrea to the genus Tatumella emend. as Tatumella citrea comb. nov., Tatumella punctata comb. nov. and Tatumella terrea comb. nov. and description of Tatumella morbirosei sp. nov. Int J Syst Evol Microbiol 60, 484-494.

Brady, C. L., Goszczynska, T., Venter, S. N., Cleenwerck, I., De Vos, P., Gitaitis, R. D. \& Coutinho, T. A. (2010c). Pantoea allii sp. nov., a novel species isolated from onion and onion seed. Int J Syst Evol Microbiol 60, 932-937.

Cleenwerck, I., Vandemeulebroecke, K., Janssens, D. \& Swings, J. (2002). Re-examination of the genus Acetobacter, with descriptions of 
Acetobacter cerevisiae sp. nov. and Acetobacter malorum sp. nov. Int J Syst Evol Microbiol 52, 1551-1558.

Coenye, T., Falsen, E., Vancanneyt, M., Hoste, B., Govan, J. R. W., Kersters, K. \& Vandamme, P. (1999). Classification of Alcaligenes faecalis-like isolates from the environment and human clinical samples as Ralstonia gilardii sp. nov. Int J Syst Bacteriol 49, 405413.

De Vuyst, L., Camu, N., De Winter, T., Vandemeulebroecke, K., Van de Perre, V., Vancanneyt, M., De Vos, P. \& Cleenwerck, I. (2008). Validation of the (GTG)(5)-rep-PCR fingerprinting technique for rapid classification and identification of acetic acid bacteria, with a focus on isolates from Ghanaian fermented cocoa beans. Int J Food Microbiol 125, 79-90.

Dice, L. (1945). Measurement of the amount of ecological association between species. Ecology 26, 297-302.

Dye, D. W. (1968). A taxonomic study of the genus Erwinia. I. The "amylovora" group. N Z J Sci 11, 590-607.

Ezaki, T., Hashimoto, Y. \& Yabuuchi, E. (1989). Fluorometric deoxyribonucleic acid-deoxyribonucleic acid hybridization in microdilution wells as an alternative to membrane filter hybridization in which radioisotopes are used to determine genetic relatedness among bacterial strains. Int J Syst Bacteriol 39, 224-229.

Felsenstein, J. (1985). Confidence limits on phylogenies: an approach using the bootstrap. Evolution 39, 783-791.

Gardan, L., Christen, R., Achouak, W. \& Prior, P. (2004). Erwinia papayae sp. nov., a pathogen of papaya (Carica papaya). Int J Syst Evol Microbiol 54, 107-113.

Geider, K., Auling, G., Du, Z., Jakovljevic, V., Jock, S. \& Völksch, B. (2006). Erwinia tasmaniensis sp. nov., a non-phytopathogenic bacterium from apple and pear trees. Int J Syst Evol Microbiol 56, 2937-2943.

Gevers, D., Huys, G. \& Swings, J. (2001). Applicability of rep-PCR fingerprinting for identification of Lactobacillus species. FEMS Microbiol Lett 205, 31-36.

Goris, J., Suzuki, K., De Vos, P., Nakase, T. \& Kersters, K. (1998). Evaluation of a microplate DNA-DNA hybridization method compared with the initial renaturation method. Can J Microbiol 44, 11481153.

Goto, M. (1976). Erwinia mallotovora sp. nov., the causal organism of bacterial leaf spot of Mallotus japonicus. Int J Syst Bacteriol 26, 467473.

Hao, M. V., Brenner, D. J., Steigerwalt, A. G., Kosako, Y. \& Komagata, K. (1990). Erwinia persicinus, a new species isolated from plants. Int J Syst Bacteriol 40, 379-383.

Harada, H., Oyaizu, H., Kosako, Y. \& Ishikawa, H. (1997). Erwinia aphidicola, a new species isolated from pea aphid, Acyrthosiphon pisum. J Gen Appl Microbiol 43, 349-354.

Hauben, L., Moore, E. R. B., Vauterin, L., Steenackers, M., Mergaert, J., Verdonck, L. \& Swings, J. (1998). Phylogenetic position of phytopathogens within the Enterobacteriaceae. Syst Appl Microbiol 21, 384397.

Higgins, C. F., Ames, G. F. L., Barnes, W. M., Clement, J. M. \& Hofnung, M. (1982). A novel intercistronic regulatory element of prokaryotic operons. Nature 298, 760-762.

Hosni, T. (2010). Interaction between Pseudomonas savastanoi $p v$. savastanoi, the causal agent of olive knot, and the endophytic bacterial species associated with the knot. $\mathrm{PhD}$ thesis, University of Perugia, Italy, pp. 108.

Hulton, C. S. J., Higgins, C. F. \& Sharp, P. M. (1991). ERIC sequences: a novel family of repetitive elements in the genomes of Escherichia coli, Salmonella typhimurium and other enterobacteria. Mol Microbiol 5, 825-834.

Kim, W.-S., Gardan, L., Rhim, S.-L. \& Geider, K. (1999). Erwinia pyrifoliae sp. nov., a novel pathogen that affects Asian pear trees (Pyrus pyrifolia Nakai). Int J Syst Bacteriol 49, 899-906.

López, M. M., Roselló, M., Llop, P., Ferrer, S., Christen, R. \& Gardan, L. (2011). Erwinia piriflorinigrans sp. nov., a novel pathogen that causes necrosis of pear blossoms. Int J Syst Evol Microbiol 61, 561567.

Marchi, G., Sisto, A., Cimmino, A., Andolfi, A., Cipriani, M. G., Evidente, A. \& Surico, G. (2006). Interaction between Pseudomonas savastanoi pv. savastanoi and Pantoea agglomerans in olive knots. Plant Pathol 55, 614-624.

Mergaert, J., Hauben, L., Cnockaert, M. C. \& Swings, J. (1999). Reclassification of non-pigmented Erwinia herbicola strains from trees as Erwinia billingiae sp. nov. Int J Syst Bacteriol 49, 377-383.

Mesbah, M., Premachandran, U. \& Whitman, W. B. (1989). Precise measurement of the $\mathrm{G}+\mathrm{C}$ content of deoxyribonucleic acid by highperformance liquid chromatography. Int J Syst Bacteriol 39, 159167.

Neto, J. R., Robbs, C. F. \& Yamashiro, T. (1987). A bacterial disease of guava (Psidium guajava) caused by Erwinia psidii sp. nov. Fitopatol Bras 12, 345-350.

Niemann, S., Pühler, A., Tichy, H.-V., Simon, R. \& Selbitschka, W. (1997). Evaluation of the resolving power of three different DNA fingerprinting methods to discriminate among isolates of a natural Rhizobium meliloti population. J Appl Microbiol 82, 477-484.

Ouzari, H., Khsairi, A., Raddadi, N., Jaoua, L., Hassen, A., Zarrouk, M., Daffonchio, D. \& Boudabous, A. (2008). Diversity of auxinproducing bacteria associated to Pseudomonas savastanoi-induced olive knots. J Basic Microbiol 48, 370-377.

Quesada, J. M., García, A., Bertolini, E., López, M. M. \& Penyalver, R. (2007). Recovery of Pseudomonas savastanoi pv. savastanoi from symptomless shoots of naturally infected olive trees. Int Microbiol 10, 77-84.

Rademaker, J. L. W. \& de Bruijn, F. J. (1997). Characterization and classification of microbes by rep-PCR genomic fingerprinting and computer-assisted pattern analysis. In Protocols, Application and Overviews, pp. 151-171. Edited by G. Caetano-Anolles \& P. Gressfoff. New York: J. Wiley and Sons.

Roberts, P. (1974). Erwinia rhapontici (Millard) Burkholder associated with pink grain of wheat. J Appl Bacteriol 37, 353-358.

Rojas, A. M., de los Rios, J. E., Fischer-Le Saux, M., Jimenez, P., Reche, P., Bonneau, S., Sutra, L., Mathieu-Daudé, F. \& McClelland, M. (2004). Erwinia toletana sp. nov., associated with Pseudomonas savastanoi-induced tree knots. Int J Syst Evol Microbiol 54, 22172222.

Schaad, N. W., Jones, J. B. \& Chun, W. (2001). Initial identification of common genera. In Laboratory Guide for Identification of Plant Pathogenic Bacteria, 3rd edn, pp. 84-120. Edited by N. W. Schaad, J. B. Jones \& W. Chun. St Paul, MN: APS.

Sisto, A., Cipriani, M. G. \& Morea, M. (2004). Knot formation caused by Pseudomonas savastanoi subsp. savastanoi on olive plants is hrpdependent. Phytopathology 94, 484-489.

Stackebrandt, E. \& Goebel, B. M. (1994). A place for DNA-DNA reassociation and 16S rRNA sequence analysis in the present species definition in bacteriology. Int J Syst Bacteriol 44, 846-849.

Suslow, T. V., Schroth, M. N. \& Isaka, M. (1982). Application of a rapid method for Gram differentiation of plant pathogenic and saprophytic bacteria without staining. Phytopathology 72, 917918. 
Versalovic, J., Koeuth, T. \& Lupski, J. R. (1991). Distribution of repetitive DNA sequences in eubacteria and application to fingerprinting of bacterial genomes. Nucleic Acids Res 19, 6823-6831.

Versalovic, J., Schneider, M., de Bruijn, F. P. \& Lupski, J. R. (1994). Genomic fingerprinting of bacteria using repetitive sequence-based polymerase chain reaction. Methods Mol Cell Biol 5, 25-40.

Wayne, L. G., Brenner, D. J., Colwell, R. R., Grimont, P. A. D., Kandler, O., Krichevsky, M. I., Moore, L. H., Moore, W. E. C., Murray, R. G. E. \& other authors (1987). International Committee on Systematic Bacteriology. Report of the ad hoc committee on reconciliation of approaches to bacterial systematics. Int J Syst Bacteriol 37, 463-464.

Wilson, K. (1987). Preparation of genomic DNA from bacteria. In Current Protocols in Molecular Biology, pp. 2.4.1-2.4.5. Edited by F. M. Ausubel, R. Brent, R. E. Kingston, D. D. Moore, J. G. Seidman, J. A. Smith \& K. Struhl. New York: Green Publishing and WileyInterscience. 